\title{
Empathy: simple and inevitable? Development education and narratives of African poverty
}

\author{
Nomisha C. Kurian* - Yale University, USA
}

\begin{abstract}
This article critically examines how the concept of empathy is mobilized in the rhetoric of development education, and explores different ways of conceptualizing empathy as a pedagogical ideal and an affective experience. Its premise is that the concept of empathy has been insufficiently probed within academia, even though paradigm shifts in development have made the concept central to development education. In reference to narratives of African poverty, the article critiques literature depicting empathy as simple or inevitable within development education. It seeks to open up new possibilities for conceptualizing a form of empathy that prioritizes nuance and self-reflexivity. The article intends to contribute to development education by advocating more respectful, dialogical and self-aware cross-cultural engagement.
\end{abstract}

Keywords: empathy; development education; postcolonialism; global citizenship

\section{Introduction}

She had felt sorry for me even before she saw me; her default position towards me as an African was a kind of patronizing, well-meaning pity. My room-mate had a single story of Africa, a single story of catastrophe. In this single story there was no possibility of Africans being similar to her in any way, no possibility of feelings more complex than pity, no possibility of a connection as human equals ... if all I knew of Africa were from popular images, I too would think that Africa was a place of beautiful landscapes, beautiful animals, and incomprehensible people fighting senseless wars, dying of poverty and AIDS, unable to speak for themselves and waiting to be saved. (Adichie, 2009: 04:13)

Although development education aspires towards intercultural understanding, the Nigerian novelist Chimamanda Adichie, discussing her first encounter in the West, poignantly illustrates the reality of division and difference. Reductive narratives about developing regions not only misrepresent peoples and cultures, but also erect barriers to empathy. This is concerning because empathy powerfully enriches human relationships. In fact, references to it have increased over the past decade. In The Audacity of Hope, Barack Obama (2006) asks society to mend its 'empathy deficit'; primatologist Frans de Waal (2010) states that we are wired for connection in his bestseller, The Age of Empathy; social scientist Jeremy Rifkin's (c2009: 616) The Empathic Civilization claims that our technological progress gifts us 'universal empathic connectivity'. This article critically examines the place of empathy in development education, but not to jettison it as an ideal. In fact, the article is predicated on the assumption that because empathy 
is so valuable, it deserves academic scrutiny. I seek a conceptualization of empathy that helps students understand and feel for those who deserve to have their needs and rights met, but in a way that is respectful and mindful of complexity and context.

The first section justifies this choice of focus. It defines key terms and situates empathy within paradigm shifts in development. Using the example of narratives about African poverty, the second and third sections engage with theories of postcolonialism, empathy and critical pedagogy. The second section critiques literature depicting empathy as simple or inevitable within development education. The third section seeks to open up new possibilities for conceptualizing empathy. It synthesizes relevant literature to argue that when learning about African poverty, the empathy students experience should include two elements. One is nuance: students should respect the agency and multidimensionality of the Other without internalizing simplistic narratives. The second is self-reflexivity: students should be aware of their privilege and positionality, and the historical, geopolitical and sociocultural inequalities that mediate their relationship with the Other.

The article is situated within the context of the United Kingdom. To clarify educational references made: Key Stages 1-4 refer to the different levels at which students in England from age 5 to age 16 learn the national curriculum (the standardized set of subjects that all state primary and secondary schools follow). The article also mentions Year 7 and Year 9, terms that refer to students aged 11-12 and 13-14 respectively. The Department for Education and Skills (DfES) was a former term for the contemporary Department for Education (DfE) in England, while the Department for International Development (DFID) is England's governmental department in charge of overseas aid.

This article follows Etherington's (2004) recommendation to qualitative researchers to be transparent about their personal positionality and the motivations underlying their research. Hence, I disclose that I was born in the Global South, but undertook undergraduate and graduate study in England. My personal connection to the developing world and the UK has deepened my desire to research ethical crosscultural engagement. This article is driven by the conviction that, as a way to try and understand the ever-changing and multidimensional realities of others, empathy is both deeply complex and deeply worthwhile.

\section{Context}

What is empathy, and why is it worth academic analysis by development educators? By providing a rationale for this focus and defining key terms, this section seeks to answer this question.

Empathy, as a rich and multifaceted concept, assumes different meanings in different disciplines. For example, sociologists examine how the ability to understand another person is shaped by culture, gender, race and other markers of identity (Gillborn, 2008; Pedwell, 2012). Neuroscientists discuss mirror neurons, brain cells that form the neural basis for empathy (Gallese, 2001). Philosophers describe empathy as a vivid imagining of another's predicament that dissolves the boundaries between 'self' and 'other' (Nussbaum, 2013). Thus, each discipline probes different dimensions of empathy.

But despite these analytical variations, empathy is generally conceptualized as the ability to understand (and to be moved by) another person's perspective. It may be a cognitive response, if a person actively tries to comprehend another person's world views and beliefs (Krznaric, 2008). It may also be an affective (emotional) response, if 
a person feels what another person feels after observing them or listening to their narrative; for example, feeling distressed upon witnessing suffering (Krznaric, 2008). Hence, empathy can be defined as a cognitive and/or affective process that involves understanding the perspective and positioning of another person or persons. The concept can be debated from diverse perspectives (for a psychological critique, see Bloom, 2017; for a biological defence, see De Waal, 2010). However, this article chooses a sociological perspective to spotlight issues of power, positionality and privilege central to development education.

The term 'development education' is useful because of its broad scope. UK development education emerged in the 1970s to answer the call by the United Nations for education to highlight 'human rights ... and social justice in ... developing countries' (UN, 1975, as cited in Bourn, 2008: 6). Striving to make students aware of inequality, development education encompasses both global citizenship initiatives and social science classes that teach about developing countries (Tallon, 2013). It encourages North-South school partnerships, discussions of NGO-produced material, student engagement with charities and a range of other activities (Bourn, 2015). Thus, the breadth offered by the term makes it a promising avenue to investigate empathy.

Empathy-centred discourse entered international development during the 1980s, accompanying critique of the field's entrenched inequalities. For example, the Global North was accused of neocolonialism - that is, reproducing old colonial hierarchies through top-down management of the South (Tikly, 2004). Several development practices, such as the World Bank's structural adjustment policies, began to be criticized for detrimentally impacting developing nations (Leys, 1996; Pieterse, 1991). Modernization theory, which universalized a Eurocentric vision of development (Rostow, 1960), was accused of overlooking the agency and unique world views of local Southern peoples (Tucker, 2001). In response, more participatory ideas of development emerged. The influential Latin American educator Paulo Freire (1972: 96) called for 'immediate empathy'. Freire (1972: 96) declared, 'It is not our role to speak to the people about our own view of the world or impose that view on them, but rather to dialogue with the people about their view', and advocated that development practitioners understand people's 'preoccupations, doubts, hopes and fears.' Thus, empathy became necessary to participatory development as a means of respecting the perspectives of local communities and giving them ownership of the development process.

With the rise of participatory development, development paradigms now recognize the importance of empathy in empowering local populations to realize their own vision of development (Pedwell, 2012). For example, development professionals live with poor families in 'immersion', an experiential learning programme recommended by the World Bank, ActionAid and the Institute of Development Studies. They are expected to 'see the world the other way around' from 'the perspective of people living in poverty' (Chambers, 2007: 11). Thus, to achieve grassroots empowerment, empathy has been embedded within development strategies. This paradigm shift has amplified the importance of empathy in development education.

Empathy is invoked even in one of the earliest roots of development education: UNESCO's 1974 'Recommendation concerning Education for International Understanding' (co-signed by the UK). It recommends 'an international and global perspective' in education that gives students an 'understanding and respect for all peoples, their cultures, civilizations, values and ways of life' (UNESCO, 1974: 148). Similarly, the word 'empathy' recurs in national policy. In 2005, the UK DfES published 
Developing the Global Dimension in the School Curriculum, a guide to teaching about inequality in developing countries. The guide envisioned 'understanding the importance of empathy', ' developing empathy for other people's needs ... from a range of cultures' and 'developing children's understanding beyond their own experience' as key educational outcomes (DfES, 2005: 14, 16, 21). The Qualifications and Curriculum Authority (QCA; 2007: 18) recommended a global curriculum that would 'explore other people's perspectives' and 'different cultures and ways of life'. The DfES (2004: 1) also advocated that children 'understand the values and cultures of different societies' in its report, Putting the World into World-Class Education. Similarly, the Department for International Development (DFID) funded a teacher education project in 2012 that stated that 'the global dimension has been shown to enhance pupils' empathy ... and how they relate to others' (McGough and Hunt, 2012: 3). The concept of empathy has thus been naturalized as a normative ideal. It is mobilized by educators and policymakers to promote the idea of a global curriculum that fosters intercultural understanding.

Yet, paradoxically, despite the plethora of publications referencing empathy, there is a paucity of research problematizing it. For example, a well-known analysis is an Oxfam report on 'empathy education' (Krznaric, 2008). Although it thoughtfully captures the value of empathy, its 'global empathy' section is perhaps oversimplified:

Children need to be encouraged to empathise with people who live in other countries, especially those in developing countries whose lives are very different from their own, as a way of promoting the idea of global citizenship. Why should a child at school in England, for instance, not be taught to empathise with the plight of a flood victim in the Indian state of Orissa, or with a child who has been injured in an earthquake in China? (Krznaric, 2008: 41)

However, there may well be reasons to be wary of uncritically telling a child in England to empathize in such a manner. Portraying developing countries as victims can reinscribe problematic stereotypes, and differences in privilege and positionality can hinder cross-cultural empathy, as is discussed later. A lack of criticality is also evident in other publications depicting empathy as a natural outcome of development education (DfES, 2005, 2004; McGough and Hunt, 2012).

However, critique seems necessary, because these discursive spaces are never neutral or apolitical. For example, DfES (2004: 1) states that teaching children to be empathetic - and consequently open to different cultures - results in 'real and significant benefits for the UK ... in an increasingly interdependent world'. These benefits include 'additional income' from international partnerships, increased 'export potential' and 'new overseas markets' in the 'global economy' (DfES, 2004: 19). Thus, empathy is not only a benevolent ideal but also construed as a tool for national selfinterest within neo-liberal markets. Globalization is an overarching backdrop to this, since distant events in the Global South now have direct repercussions for the Global North (Giddens, 1991). Technology has quickened information flows and the influx of multicultural spaces and ideologies has further blurred boundaries between the local and the global (Appadurai, 1996). Consequently, the concept of empathy has magnified in importance as policymakers and educators emphasize the world's interdependence (Miles, 2004).

However, empathy seems to be under-researched, perhaps because, as Pedwell (2012) notes, it is seen as a natural good. There is a nascent trend of exploring the transnational politics of empathy and its role in social justice (see Pedwell, 2012; 
Recuber, 2015), but little research about the place of empathy in development education specifically. Hence, this lacuna in the literature is an exciting opportunity to denaturalize empathy and investigate its implications, as any concept so frequently invoked should be critically probed.

To conduct this analysis, I have chosen the example of African poverty for two reasons. First, the 2015/16 Global Monitoring Report shows that 13 of the 15 poorest countries are located in Africa, and Sub-Saharan Africa hosts 43 per cent of the world's poorest people (World Bank Group, 2016). Hence, much of development education literature explores pedagogy about Africa. Second, aside from education, the literature suggests that Africa is central to how the Global North imagines and represents Southern poverty in its popular media (Mahadeo and McKinney, 2007). The first visual narratives of African poverty on British television arrived during the Nigerian Civil War (1967-70), followed by the 1985 Band Aid campaigns about Ethiopia's drought (Borowski, 2012). Fundraising advertisements emphasizing Africa's poverty are still common (Harrison, 2013). Such media may propagate deficit discourses - that is, ideas about Africa 'lacking' material, cultural or symbolic resources (Dogra, 2013). Since many students from Key Stages 1-4 are exposed to the media, it is possible that deficit discourses influence their perceptions of Africa. The question of how to cultivate empathy in light of students' pre-existing prejudices thus becomes pertinent to development education.

This review focuses on Key Stages 1-4 because research indicates that these formative years shape children's perceptions, and may transmit stereotypes that continue well into adulthood (Wiegand, 1992). Rather than naming specific African countries, I use the term 'Africa' to reflect the way in which Africa is often portrayed as an undifferentiated mass. Studies indicate that broad-brush, generic assumptions about Africa are frequently made, without recognition of its diversity and heterogeneity (Dogra, 2013; Lundy and Negash, 2013). Thus, I refer to 'Africa' to emphasize how the word represents not only a continent, but also an aggregate of stereotypes and misconceptions. I also use the term 'Global South' to signify developing countries in Asia, Africa, Latin America and the Middle East. These countries have high levels of poverty, low living standards and, typically, histories of colonialism (Connell, 2007). I use the term 'Global North' to refer to developed, industrialized nations with high living standards. It must be admitted that this binary is imperfect. Bajaj (2015) points out that poor inner-city Northern communities are not dissimilar to those in the South, and wealthy elites in the South resemble those in the North. Thus, these terms are contested sociopolitical constructs rather than fixed geographical truths. They are, however, useful for describing deep-seated patterns of inequality (see Sutcliffe, 2001).

\section{Problematizing the ideal of empathy}

Postcolonial theory can help problematize two assumptions in the literature: first, that empathy is a simple process, and second, that it is an inevitable outcome of development education. Two Southern theorists, in particular, provide valuable analytical frameworks: Gayatri Spivak and Vanessa Andreotti.

Indian scholar Gayatri Spivak (1988) argues that knowledge forged about a different culture is never innocent. Likening the dissemination of knowledge about the Other to the export of raw materials from colonized nations, Spivak argues that the North has historically produced paternalistic representations of the South for its own benefit, to fortify its own power. Spivak's theories underpin my exploration of empathy because her emphasis on power dynamics has significant implications for 
North-South relations in development education. For similar reasons, the work of the Brazilian development educator, Vanessa Andreotti, also forms a useful theoretical lens. Andreotti (2006b) draws on postcolonialism to expand the scope of development education. She builds on Spivak's ideas to distinguish between 'soft' and 'critical' global citizenship, a distinction that will later be explored as it demarcates the difference between problematic and promising North-South relations.

\section{Is empathy a simple process?}

A flaw in the literature appears to be the uncritical endorsement of empathy. To return to Oxfam's 'empathy education' report: it states that there is no reason why a child in England should not be taught to empathize with victims of disaster in developing countries (Krznaric, 2008: 41). However, this statement is problematic because it ignores the larger geopolitical context mediating the affective relationship between this child and the Southern 'victim'. Hence, its portrayal of empathy is dehistoricized and depoliticized. Other literature similarly advocates empathy as a tool for social justice without probing its context (QCA, 2007; DfES, 2005, 2004). This uncritically positive outlook is traceable to progressive educators such as John Dewey, especially after the Second World War, who saw our 'social imaginations' as vital to building compassionate democracies (Boler, 1999). Although this ideal seems worthwhile, such discourses may err in tacitly assuming that empathy is simple.

Empathy is a relational concept. In development education, it involves the responder (the empathetic student) and the subject (typically a Southern individual or group depicted as suffering or vulnerable). To analyse this relationship, the postcolonial idea of alterity is useful. Andreotti (2006a) explains that alterity means that to construct our own identities, we define who we are not. To have an 'Us', we must have an 'Other'. Hence, development education, in an echo of colonialism, may reinscribe uneven power relations between the Northern student as a superior Us and the Southern subject of empathy as a helpless Other.

To historicize and politicize empathy in development education, postcolonial theory is helpful because it explores how colonial hierarchies are reproduced today. Two seminal works, Fanon's (1963) The Wretched of the Earth and Said's (1978) Orientalism, illuminate how colonizers considered Africans vulnerable, irrational and flawed beings, only redeemable through European codes and practices. In this context, alterity, or the erection of divisions between Us and them/the Other was a vehicle of power: the binary between superior colonizers ('Us') and infantile natives ('them/the Other') underpinned the civilizing mission (Cooper, 1997). It has been argued that this binary is reinforced by NGO images of African deprivation (Kleinman and Kleinman, 1996; Hopkins and Sriprakash, 2016). The literature reveals that stereotypes about Africa being defined by misery, disease and despair are still common. Analyses of Western media show Africa traditionally associated with images of hunger, war and AIDS (Bunce et al., 2017; Mahadeo and McKinney, 2007; VSO, 2002). Burman (1994) notes that these images often portray African children, in particular, as lone figures, cut off from kin and government. Hence, by implying societal neglect, they diminish the agency of Southern peoples and legitimate external Western intervention (Kleinman and Kleinman, 1996).

Moreover, Manzo (2008) argues that narratives portraying poor Africans as isolated victims and faraway viewers as potential saviours evoke the idea of the 'white man's burden'. Since the tropes of innocence, infantilization, dependence and protection buttressed the civilizing mission, aid can reinscribe colonial binaries. Thus, postcolonial theory is valuable for development education because it helps one 
decipher the covert meanings and power hierarchies embedded within pernicious narratives of deprivation. In light of Andreotti's (2006a) note on alterity - the relationship of self and Other - perhaps this implies that before expecting students to empathize, development education must be thoughtful about how it presents the subject of empathy.

This thoughtfulness seems vital, considering how deficit discourses influence students. Despite policies aimed at teaching understanding and respect of Southern cultures (DfES, 2005), some literature shows UK students caricaturing Africa as a land of mud huts and dirty drinking water, fitting into a larger pattern of Northern students seeing Africa solely in terms of destitution (Lewis, 2016; Sarti et al., 2015; Elton-Chalcraft, 2009). Development education initiatives may not always eradicate such perceptions. For example, in Brown's (2006) study, UK students showed a distinct lack of empathy. They characterized their relationship with their South African partner school as 'give and take. We give them money, they take it' (Brown, 2006: 12). They also said, 'We can help them - they don't have anything better to do' (Brown, 2006: 12). This contradicts the government's vision that school partnerships 'challenge the stereotyped, problem orientated image of people in less affluent countries' (DfEE, 2000: 14). In fact, it suggests that development education may perpetuate stereotypes, if students view poor Africans as victims to be saved. Andreotti (2006b) warns of this risk in her conceptualizing of 'soft' global citizenship, which positions Southern peoples as helpless and infantilized, and triggers feelings of self-righteousness or moral superiority in the Northern student. True empathy between equals seems impossible if students believe they are 'benevolent, charitable and innocent people helping the poor' (Alasuutari and Andreotti, 2015: 65), a paternalistic dynamic that embodies asymmetrical power relations. Moreover, considering the existence of 4.1 million children living in poverty within the UK itself, the binary between the 'privileged' Northern student and the 'poor' African proves doubly simplistic (Social Metrics Commission, 2018). If African poverty is overly exoticized, development education might miss the reality that some of the UK students being asked to empathize with distant Others may be experiencing similar forms of poverty themselves. A valuable form of solidarity, and the recognition that privilege is relative rather than absolute, might thus be lost.

Decontextualized pedagogy can aggravate the perceived binary. In Smith's (1999: 493) study of an English school sponsoring a Ugandan child, a teacher admitted that she never raised political issues for fear that students would 'switch off'. Consequently, students remained unaware of the context behind Ugandan poverty. This pedagogical omission reflects Spivak's (1990) idea of sanctioned ignorance about forgotten histories. For Spivak, sanctioned ignorance means that modernizing discourses relegate imperialism firmly to the past, disavowing its damage and giving the illusion that it does not impact current events. Ahistorical pedagogy, such as that observed by Smith, can be said to represent sanctioned ignorance. Consequently, it may not be conducive to empathy because, stripped of all context about the larger geopolitical inequalities that produce present-day injustice, poor Africans simply become distant, exoticized victims.

Thus, empathy does not seem like a simple process. The literature suggests that students may have reductionist perceptions of African poverty stemming from historical power imbalances, the dominance of disempowering narratives in the media and/ or decontextualized pedagogy. This poses a challenge for development education: efforts to spark empathy should not legitimize deficit or neocolonial discourses about the suffering Other, or perpetuate a strict binary between the privileged and the nonprivileged that ignores the reality of poverty on both sides. 


\section{Is empathy inevitable?}

Aside from the assumption that empathy is simple, another assumption is implicit in the literature: that empathy is inevitable. The literature earlier mentioned depicts empathy, in the form of respectful cross-cultural understanding, as the natural outcome of development education (DfES, 2005, 2004; QCA, 2007). For example, a DfES (2005: 14) report lists activities that expose students to other cultures and then states, 'By doing this they can develop an empathy for other people's needs'. However, in reality, this process may not be so straightforward. For instance, in Tallon's (2012) study, a teacher taught students about Niger's water shortage, hoping to motivate them to fundraise. However, the teacher reported that students felt pity, not empathy. They felt sorry for Nigeriens but were reluctant to take action. Perhaps this was because, as Tallon (2012) concludes, the Other was portrayed with no agency. No Nigerien perspectives were spotlighted, nor was the larger sociopolitical context explained. (For instance, how colonial legacies may have hindered current access to resources; see Lautze and Giordano (2005) for an analysis of how colonial transboundary water laws currently influence conflicts over water in Sub-Saharan Africa). There was no critique of external NGOs in Niger for not consulting locals. The teacher deemed such critique 'too high-level for these kids' (Tallon, 2012: 15). Hence, the voice of the Other went unheard, which might have diminished students' capacity for empathy. Andreotti (2006b) suggests that for critical global citizenship, students should engage with varied local perspectives, including dissenting voices, to recognize the complexity of Southern realities. Extending Andreotti's point, I suggest that empathy might be difficult if the curriculum omits these local voices and depicts the Other as a faraway, silent population.

Development education literature also suggests another reason why empathy is not inevitable: students are not passive recipients of information. Tallon's (2012: 15) participant teacher assumed that critique would be too 'high-level'. Yet, when Tallon (2012) showed students an NGO poster of an African child, they themselves were critical. One boy said he was not empathetic because he thought NGOs were unduly manipulative, and images of suffering African children were staged. Interestingly, his comments are echoed by academics who have questioned the politics of humanitarian representation (Chouliaraki, 2010; Perugini and Zucconi, 2017). Moreover, other studies also show UK students pointing out problematic power dynamics behind images of Africa (Brown, 2015a). Thus, this boy's lack of empathy is not necessarily a failure on his or the teacher's part. He displayed the independent-mindedness that Andreotti (2006b: 49) considers essential to critical global citizenship, which aims to let students 'experiment with other forms of seeing/thinking and being/relating to one another'. Hence, challenging moments can be reconceived as opportunities for discussion. Perhaps development education should not view empathy as inevitable, but should gently encourage students to reflect on how particular discourses and representations sway their empathy (or their initial lack of it!).

\section{Ways forward?}

What steps might teachers and youth workers take to tackle the challenge of empathy being neither simple nor inevitable? As Andreotti (2016: 109) suggests, academia should not completely 'crush generosity and altruism' in the name of critique. The literature suggests that empathy is still a worthy ideal if two elements imbue it: nuance and self-reflexivity. 


\section{Nuance}

Spivak (1988) stresses the importance of 'unlearning': discarding stereotypes, confronting internalized biases, and questioning old ways of knowing. Kapoor (2004), Beverley (1999) and Moore-Gilbert (1997) note that this necessitates contesting normalized knowledge and dominant, seemingly self-evident assumptions. Kapoor (2004: 642) pithily adds that unlearning means 'stopping oneself from always wanting to correct, teach, theorise, develop, colonise, appropriate, use, record, inscribe, enlighten'. If these ideas are synthesized, ways emerge to help students 'unlearn' and empathize with an Other whose complexity they recognize. Such pedagogy could be particularly helpful for young children because, as Lundy (2013) points out, remedying misconceptions and stereotypes as soon as possible could drive children to develop more sophisticated knowledge and more effective initiatives for social action as they grow older.

One way in which teachers or youth workers could bring nuance into narratives about African poverty is to emphasize the uniqueness of localities and nations within Africa, complicating simplistic narratives. For instance, Burns Knight (2014: n.p.), author of Africa is Not a Country, presents two contrasting lists about the continent. List A contains facts such as 'People of many African cultures eat bugs', while List B contains facts such as 'Kenyan Wangari Maathai was awarded the Nobel Peace Prize for her environmental work in 2004', stressing Africa's contribution to world history. Burns Knight observes that teachers usually consider List B more respectful and interesting. She explains that List A appears on a 2006 National Geographic map, and questions why exoticized facts, such as 'People of many African cultures eat bugs' are meant to represent an entire continent. She created List B to elicit appreciative responses and spotlight under-represented African accomplishments. Burns Knight's approach suggests that development education should aim to evoke empathy through narratives of multiplicity and diversity, deconstructing popular perceptions about who the subject of empathy is in the first place.

In this regard, another example of sound practice might be the outreach programme of the University of Leeds Centre for African Studies, African Voices. It trains African postgraduates to dispel primary schoolchildren's misconceptions about Africa. Borowski's (2012) research shows how, before meeting the postgraduates, pupils possessed one-dimensional perceptions. Labelling Africa 'starving' and 'primitive', they could not imagine Africans enjoying any of the UK's technological or industrial resources. For example, over 70 per cent believed that no Africans owned mobile phones, and over 65 per cent believed no skyscrapers existed in Africa. Empathy seems difficult for children who visualize Africa thus, as an alien Other. These findings reflect a larger research pattern of British students believing that the UK and Africa have little in common (Tallon, 2013; QCA, 2007), exemplifying the literature on stereotypes discussed previously. However, Borowski's study is different because it also offers hope for change.

Like many postcolonial theorists, Spivak and Andreotti advocate 'de-centring' perception (Landry and MacLean, 1996). De-centring is a transformative epistemological process that helps knowers become open to difference. Knowers abandon the fallacy of thinking that their culture is the centre of the world (Alasuutari and Andreotti, 2015). This suggests that empathy entails not only a gain - in understanding another's perspective - but also a loss - in having to cast aside previously held knowledge. This process is evident in Borowski's (2012) study. The children's old conceptions disintegrated after listening to the African postgraduates, but transformed into a richer understanding. 
Over 72 per cent said they now knew that African skyscrapers exist, and over 90 per cent knew that mobile phones did too. They recognized cross-cultural commonalities, evincing a widening of mental horizons. One pupil said, 'I thought all the buildings would be different but they were like what we've got'; another noted 'I didn't know they had cars, I thought they had to walk'; a third observed, 'I learnt that there are wealthy people in Africa as well', while a fourth said, 'I didn't know that there was that much technology in Africa' (Borowski, 2012: 5). Unlearning pre-existing biases, as Spivak (1988) recommends, can thus help students de-centre their world views and see the subject of their empathy as not alien to themselves. Meeting financially secure, highly educated and accomplished postgraduates from the supposedly 'primitive' continent made children reconceptualize Africa as 'welcoming, friendly and lively' instead of as 'starving, thirsty and primitive' (Borowski, 2012: 5). Therefore, victimcentred narratives might be countered with face-to-face reminders of African people's agency. Consequently, students might experience a nuanced form of empathy by learning with and from the Other, rather than about the Other (Jefferess, 2008).

Another possibility might be to use creative counters to monolithic views of African poverty. An example is Acquah et al.'s (2017) Everyday Africa: 30 photographers re-picturing a continent. To challenge sensationalized portrayals, the authors capture ordinary citizens' lives. Their images stress agency and accomplishment, from fashion parades to the joyous smiles of university graduates. Admittedly, this deliberately positive approach is controversial. Counterarguments claim that it obscures the reality of hardships and entrenched inequalities, making developing countries look unrealistically idyllic (Benthall, 2010; Chouliaraki, 2010). Moreover, Scott (2017) questions the dichotomy between 'bad' hegemonic narratives and 'good' countercultural narratives. He illustrates how 'good' narratives can be operated by vested interests; for instance, organizations may display positive images of Africa to brand themselves as progressive. Hence, development education should eschew 'good/bad' dualities and not present any narrative as apolitical or unequivocally good.

However, literature such as Everyday Africa might still be a valuable pedagogical tool, because micro-narratives about ordinary life might counterbalance the proliferation of bleak media images. The empathetic global citizen within development education can then transcend one-note understandings of the Other. De Oliveira Andreotti et al. (2015) argue that true global-mindedness entails acceptance of uncertainty and contingency. If this means that there is no single, easily discerned truth about other cultures, but infinite, possibly contradictory, narratives, then development education should provide students with multiple narratives that recognize the Other's agency and complexity. Empathy then becomes a means for students to 'wake up to face a plural, undefined world' (Andreotti, 2016: 109).

\section{Self-reflexivity}

The second element that I suggest should permeate empathy is self-reflexivity. Nuance, the first element, centred on conceptualizing the subject of empathy. But now it must be asked: what kind of empathy? Boler's (1997) theory of 'passive empathy' explains that empathy risks annihilating the Other. That is, if an individual tries to empathize with another's suffering only by thinking of herself and her own experiences, she risks forgetting the other person altogether. Boler (1997) argues this is tantamount to consuming the Other. She labels it 'passive' empathy because it does not move the individual to reflect upon her own role in perpetuating structural inequalities or to help transform them. Passive empathy 'produces no action for justice, but situations the 
powerful Western eye as the judging subject, never called upon to gaze at her own reflection' (Boler, 1999: 161). Hence, it seems inadequate.

The dangers of passive empathy emerge in studies where students construct notions of themselves as privileged beneficiaries compared to a less advantaged, faraway Other (Brown, 2015b; Smith, 1999). For instance, Smith (1999) finds in his study on an English school sponsoring a Ugandan child that the teacher taught students about Uganda by listing items that UK schools possess (for example, laboratory equipment) and then making students recite how Ugandan schools did not have any of these items. Smith then observed students using the purported 'deficiencies' of Africa to feel more empowered about their own nationalities. Another possibility, noted by Todd (2003) and Brown (2015a), is empathy engendering self-interest, when students begin imagining how they themselves would negotiate poverty and bypassing the views of the poor people in question. It would seem that, as an act of imagination, empathy risks 'all the vagaries and self-deceptions' that imagination entails (Recuber, 2015: 74).

A potential solution emerges in Boler's (1997) idea of complicity. She entreats us not only to make the Other our primary focus when being empathetic, but also to recognize our own complicity in oppressive structures that perpetuate the Other's suffering. This dovetails with Andreotti's and Spivak's work. Spivak (1999) argues that there are no neutral or pure discursive spaces uncontaminated by geopolitics, but she suggests that we endeavour to lay bare our own position in hegemonic systems through 'persistent critique'. Similarly, for Andreotti (2006b), self-reflexivity is what differentiates critical global citizenship from 'soft' global citizenship. Andreotti recommends that development education de-emphasizes discourses of charitable benevolence that portray an Other to be saved. Instead, students should be imbued with a sense of humility, working to dismantle systemic inequalities while learning with the Other. Andreotti conceptualizes this dynamic as aiming to be responsible towards the Other, rather than for the Other. She advocates 'critical literacies' that awaken students to the politics of knowledge production, an idea echoed in Giroux's (2011) notion of critical pedagogy and Kapoor's (2004) call for hyper-self-reflexivity. Hence, it seems that the empathetic gaze must foreground critical awareness of one's own positionality.

However, current pedagogy may not always be conducive to this self-critical form of empathy. Studies earlier discussed suggested that narratives of African poverty may omit self-reflexive analysis of how the North itself sustains this poverty (Tallon, 2012; Smith, 1999). Consequently, students might consider developing countries to be wholly responsible for their own suffering. In Brown's (2015a) study on student understandings of global poverty, Year 7 and Year 9 students ascribed the causes of poverty to internal characteristics of developing nations (such as corrupt governments and overpopulation), but not to external factors (such as neo-liberal policies or colonial epochs). This contradicts DFID's (1997: 77) vision for an education that 'gives the British people accurate, unbiased information about the causes of poverty in developing countries', and suggests that when development education encourages students to empathize, it must be careful not to suggest that developing countries are to blame for their own issues.

Elucidating the causes of African poverty is crucial because Nothias (2012) explains that media discourses often perpetuate 'Afro-pessimism', positioning Africa as a 'dark continent' that lacks the expertise to remedy itself. Borowski (2012) adds that UK aid is often idealized as the solution, while in reality, UK institutions may be part of the problem. While this article cannot exhaustively analyse the role of the West in African poverty (for influential analyses, see Easterly, 2006; Moyo, 2009; Rodney, 1972), 
it is pertinent to note Adegoke's (2018) reminder that many African dictators have been funded by Western interests selling them arms, and debts that African nations owe the UK may partially stem from contracts with Western companies. Hence, portrayals of Africa as a predestined 'dark continent' obscure the active role of Northern intervention, fitting Spivak's observation that demeaning representations of the Other may reinforce the interests of dominant powers.

Hence, a context-sensitive pedagogy might be fruitful, one that incorporates previously discussed ideas of complicity and self-reflexivity (Andreotti, 2006b; Boler, 1997; Spivak, 1999). Students could learn how historical inequalities, geopolitics and neo-liberal markets mediate their empathy. For instance, Ronnenberg (2013) explains how Western journalists tend to be concentrated in conflict-ridden African regions, producing a bleak impression of the continent as a whole as a place abundant in disaster and crisis. Teachers could use this example to explain how the media images that students consume are not rigid truths, but are sociopolitically contingent on the circumstances of production. Moreover, helpful development resources already exist that aim at engendering awareness of the structural causes of poverty through role-plays and simulations. Examples include the Paper Bag Game (which utilizes real prices and wages to demonstrate exploitative economic systems) and the Trading Game (which reveals the barriers that poor countries face in global free trade) (DevelopmentEducation.ie, 2012; Merryfield and Kasai, 2004).

Pedagogy could also, for older students, involve reflection on their own positioning within global injustice. Finnegan (2013) explains how teaching American students about the role of the US in the structural causes of African poverty made them feel infuriated and disturbed, yet motivated them to work for social change. Such pedagogy could be adapted to the UK context (for critical commentary on the educational implications of the UK's unique relationship to Africa, see Routley, 2016). Boler and Zembylas (2003: 108) call such teaching a 'pedagogy of discomfort', because recognizing severe forms of injustice, and even one's own potential role in it, may spark disillusionment or anger. But this emotional labour can empower students to take humane action and acknowledge their implication in power networks that platform certain voices and suppress others. We are 'all part of the problem and the solution' (Andreotti, 2006b: 47).

\section{Limitations}

On a cautionary note, even the type of critical empathy l advocate is not unproblematic. First, Pedwell (2014) notes that the mere act of empathy locks self and Other into fixed positions. She observes that in both academic literature and popular liberal discourse, it is usually those with existing geopolitical and socio-economic privilege (typically white, Western and middle class) who are expected to empathize with the less privileged Other. Consequently, even choosing to empathize is an expression of power that could entrench, not unsettle, inequalities (Berlant, 2004).

Second, De Oliveira Andreotti et al. (2015) consider empathy confining in its bid to find common ground. They warn that it risks repressing difference. They even critique how empathy is centred around bridging differences, and hence 'at its core, it means we can only ever be the same' (De Oliveira Andreotti et al., 2015: 255). I venture to respectfully disagree with this last statement. Liberal humanist discourses of people being 'all the same under the skin' can camouflage how people are oppressed in radically different ways (Boler and Zembylas, 2003). However, empathy transcends simplistic notions of sameness. It is an act of perspective-taking (Krznaric, 2008), and as such necessitates understanding why another is different from oneself, and 
respecting that difference, rather than forcing an artificial consensus. Nonetheless, these critiques about empathy being restrictive seem to be a valid warning. Studies suggest that people empathize more easily with, and choose to help, those from the same race, religion or gender, or those who have other shared characteristics (Bloom, 2017; Avenanti et al., 2010; Fong and Luttmer, 2009). Thus, empathy-based ideals may risk overlooking the human propensity for tribalism, and excluding those perceived as different.

Last, empathy may be dangerous if it persuades students that they fully understand vulnerable communities. Said (1978) affirms in his famous critique of modernism, Orientalism, that claims to know the Southern Other signify Northern hegemony. Said elucidates how colonizers created reductive, totalizing stereotypes about their subjects while professing to completely understand them, a process Spivak (1988: 24) calls 'epistemic violence'. Similarly, Pedwell (2012) warns that privileged parties claiming to know the experiences of the marginalized can lead to appropriation or forms of silencing that reinforce oppression. Thus, epistemologically speaking, development education should avoid grand narratives about empathy yielding a perfect understanding of the Other.

With these limitations in mind, I do not wish to suggest a 'right' version of empathy to teach, because that seems overly didactic and simplistic. Rather, this review hopes to showcase possibilities for transformative and critical pedagogy while leaving the concept of empathy open-ended and contestable.

\section{Conclusion}

Empathy is an essential tool for connection that can spark compassionate action for change. Precisely because it is so valuable, it deserves more analysis; being uncritically positive about the concept may blind us to its complications. I have sought to engage with research showing the complex workings of empathy under the auspice of development education, while critiquing policies that do not.

Policies invoke the concept as a normative ideal, both within development education and international development. But there is a dearth of literature that explores the workings and possible risks of empathy. Some policies seem to endorse empathy in an ahistorical and depoliticized manner. But, once the concept is situated within changing paradigms of international development and education, globalization and neo-liberal ideas of national self-interest, it becomes evident that empathy is inextricable from the politico-ideological spaces that legitimize it.

Two implicit assumptions in the literature are problematic: that empathy is simple and that it is inevitable. Since it is a relational concept, development educators must be mindful of how they represent the suffering Other. Postcolonial theory provides a valuable framework for locating narratives of African poverty within a larger historical and geopolitical context. A plethora of stereotypes and misconceptions can clog the affective space between a student and a distant Other. In addition, it is not inevitable that students will be immediately empathetic. If they are not initially empathetic, this is not a failure of development education. Rather, it could be an opportunity for critical dialogue about humanitarian discourse, the ethics of representation or any other issue raised therein.

Synthesizing theories of postcolonialism, empathy and critical pedagogy offers the possibility of imagining a form of empathy that challenges and provokes the learner. Two elements seem vital: nuance and self-reflexivity. Nuance might alert students to the diversity and heterogeneity of the communities studied, if multiple narratives are 
offered. Accounts about ordinary citizens' lives that display their agency and potential for flourishing seem vital to counterbalance the abundance of tragic stories in the media. Although 'positive' narratives are not unproblematic either, they do have value in complicating one-dimensional portrayals of life in a developing region. Aside from nuance, another element of this challenging form of empathy would be self-reflexivity. If students reflect on their own socio-economic and political positioning, they might become sensitive to societal power imbalances and structures that perpetuate the suffering of the Other, even systems of which they might unwittingly be a part. This empathetic imagination would not necessarily be easy or feel-good. However, it could refine students' self-awareness, humility and critical thinking skills by presenting the difficulty of shedding one's own preconceptions, and feeling discomfort at one's possible complicity in injustice.

However, on a cautionary note, I acknowledge that no conceptualization of empathy is unproblematic. No pedagogy should reproduce grand modernist narratives by leading students to assume that they fully know or understand the Other. Moreover, the very act of empathy is fraught with political overtones and the possibility of reinscribing unequal power relations. Hence, I do not want to be overly prescriptive by concluding that there is any definitively right version of empathy. In a divisive, conflictridden society, any attempt at empathy surely has some value.

But my overarching argument is that we should be wary of branding it a simple panacea for social ills, and should seek a deeper understanding of the concept that lets students understand and feel for others in a respectful and context-sensitive way. As children are curious about other people's unique ways of seeing the world, perhaps adult researchers should be curious about the very concept of empathy itself. Future research could chart the politico-affective map of empathy in more depth, and further explore how the concept is mobilized, deployed and circulated in the global imaginary.

\section{Notes on the contributor}

Nomisha Kurian is the 2018/19 Charles and Julia Henry Fellow at Yale University, researching human rights. Previously, she completed an MPhil in education, globalization and international development and a BA in education, both at the University of Cambridge. Her work spans both the sociology and psychology of education, and has most recently featured in the Journal of Peace Education and the Palgrave Handbook of Citizenship and Education.

\section{References}

Acquah, N., DiCampo, P., Merrill, A. and van der Heijden, T. (eds) (2017) Everyday Africa: 30 photographers re-picturing a continent. Heidelberg: Kehrer Verlag

Adegoke, D. (2018) 'Africa and the media'. In Akanle, O. and Adésìnà, J.O. (eds) The Development of Africa: Issues, diagnoses and prognoses. Cham: Springer, 173-88.

Adichie, C.N. (2009) The Danger of a Single Story [video]. Online. https://tinyurl.com/pp2darm (accessed 7 March 2019).

Alasuutari, H. and Andreotti, V. (2015) 'Framing and contesting the dominant global imaginary of North-South relations: Identifying and challenging socio-cultural hierarchies'. Policy and Practice: A Development Education Review, 20, 64-92.

Andreotti, V. (2006a) The Contributions of Postcolonial Theory to Development Education (DEA Thinkpiece). London: Development Education Association. Online. https://tinyurl.com/y6d5z6s5 (accessed 2 March 2019).

Andreotti, V. (2006b) 'Soft versus critical global citizenship education'. Policy and Practice: A Development Education Review, 3, 40-51. 
Andreotti, V. (2016) 'The educational challenges of imagining the world differently'. Canadian Journal of Development Studies, 37 (1), 101-12.

Appadurai, A. (1996) Modernity at Large: Cultural dimensions of globalization. Minneapolis: University of Minnesota Press.

Avenanti, A., Sirigu, A. and Aglioti, S.M. (2010) 'Racial bias reduces empathic sensorimotor resonance with other-race pain'. Current Biology, 20 (11), 1018-22.

Bajaj, M. (2015) '"Pedagogies of resistance" and critical peace education praxis'. Journal of Peace Education, 12 (2), 154-66.

Benthall, J. (2010) Disasters, Relief and the Media. Wantage: Sean Kingston Publishing.

Berlant, L. (ed.) (2004) Compassion: The culture and politics of an emotion. New York: Routledge.

Beverley, J. (1999) Subalternity and Representation: Arguments in cultural theory. Durham, NC: Duke University Press.

Bloom, P. (2017) Against Empathy: The case for rational compassion. London: Bodley Head.

Boler, M. (1997) 'The risks of empathy: Interrogating multiculturalism's gaze'. Cultural Studies, 11 (2), 253-73.

Boler, M. (1999) Feeling Power: Emotions and education. New York: Routledge.

Boler, M. and Zembylas, M. (2003) 'Discomforting truths: The emotional terrain of understanding difference'. In Trifonas, P.P. (ed.) Pedagogies of Difference: Rethinking education for social change. New York: RoutledgeFalmer, 107-30.

Borowski, R. (2012) 'Young people's perceptions of Africa'. Race Equality Teaching, 30 (3), 24-7.

Bourn, D. (2008) 'Development education: Towards a re-conceptualisation'. International Journal of Development Education and Global Learning, 1 (1), 5-22.

Bourn, D. (2015) The Theory and Practice of Development Education: A pedagogy for global social justice. London: Routledge.

Brown, K. (2006) School Linking and Teaching and Learning Global Citizenship. Canterbury: citizED.

Brown, K. (2015a) Young People's Understandings of Global Poverty (Research Paper 14). London: Development Education Research Centre.

Brown, K. (2015b) 'Theorizing learning process: An experiential, constructivist approach to young people's learning about global poverty and development'. International Journal of Development Education and Global Learning, 7 (1), 53-70.

Bunce, M., Franks, S. and Paterson, C. (eds) (2017) Africa's Media Image in the 21st Century: From the "Heart of Darkness" to "Africa Rising". London: Routledge.

Burman, E. (1994) 'Innocents abroad: Western fantasies of childhood and the iconography of emergencies'. Disasters, 18 (3), 238-53.

Burns Knight, M. (2014) 'What do we want children to learn about Africa?'. Teaching for Change, 21 February. Online. https://tinyurl.com/y3gqvgmv (accessed 7 March 2019).

Chambers, R. (2007) 'Overview: Immersions: Something is happening'. Participatory Learning and Action, 57, 9-14.

Chouliaraki, L. (2010) 'Post-humanitarianism: Humanitarian communication beyond a politics of pity'. International Journal of Cultural Studies, 13 (2), 107-26.

Connell, R. (2007) Southern Theory: The global dynamics of knowledge in social science. Sydney: Allen and Unwin.

Cooper, F. (1997) 'Modernizing bureaucrats, backward Africans, and the development concept'. In Cooper, F. and Packard, R. (eds) International Development and the Social Sciences: Essays on the history and politics of knowledge. Berkeley: University of California Press, 64-92.

De Oliveira Andreotti, V., Biesta, G. and Ahenakew, C. (2015) 'Between the nation and the globe: Education for global mindedness in Finland'. Globalisation, Societies and Education, 13 (2), 246-59.

DevelopmentEducation.ie (2012) 'The Paper Bag Game'. Online. https://tinyurl.com/y52c492f (accessed 3 March 2019).

De Waal, F. (2010) The Age of Empathy: Nature's lessons for a kinder society. New York: Three Rivers Press.

DfEE (Department for Education and Employment) (2000) Developing a Global Dimension in the School Curriculum. London: Department for Education and Employment.

DfES (Department for Education and Skills) (2004) Putting the World into World-Class Education: An international strategy for education, skills and children's services. Nottingham: Department for Education and Skills.

DfES (Department for Education and Skills) (2005) Developing the Global Dimension in the School Curriculum. London: Department for Education and Skills. Online. https://tinyurl.com/y4zdwoxm (accessed 3 March 2019). 
DfES (Department for Education and Skills) (2007) Social and Emotional Aspects of Learning for Secondary Schools (SEAL): Guidance booklet. London: Department for Education and Skills.

DFID (Department for International Development) (1997) Eliminating World Poverty: A challenge for the 21st century: A summary. London: Department for International Development.

Dogra, N. (2013) Representations of Global Poverty: Aid, development and international NGOs. London: I.B. Tauris.

Easterly, W. (2006) The White Man's Burden: Why the West's efforts to aid the rest have done so much ill and so little good. Oxford: Oxford University Press.

Elton-Chalcraft, S. (2009) It's Not Just about Black and White, Miss: Children's awareness of race. Stoke-on-Trent: Trentham Books.

Etherington, K. (2004) Becoming a Reflexive Researcher: Using our selves in research. London: Jessica Kingsley Publishers.

Fanon, F. (1963) The Wretched of the Earth. Trans. Farrington, C. New York: Grove Press.

Finnegan, A.C. (2013) 'Shaping US-based activism toward Africa: The role of a mix of critical pedagogies'. In Lundy, B.D. and Negash, S. (eds) Teaching Africa: A guide for the 21st-century classroom. Bloomington: Indiana University Press, 181-94.

Fong, C.M. and Luttmer, E.F.P. (2009) 'What determines giving to Hurricane Katrina victims? Experimental evidence on racial group loyalty'. American Economic Journal: Applied Economics, $1(2), 64-87$

Freire, P. (1972) Pedagogy of the Oppressed. Trans. Ramos, M.B. Harmondsworth: Penguin.

Gallese, V. (2001) 'The "shared manifold" hypothesis: From mirror neurons to empathy'. Journal of Consciousness Studies, 8 (5-7), 33-50.

Giddens, A. (1991) Modernity and Self-ldentity: Self and society in the late modern age. Cambridge: Polity Press.

Gillborn, D. (2008) Racism and Education: Coincidence or conspiracy? London: Routledge.

Giroux, H.A. (2011) On Critical Pedagogy. New York: Continuum.

Harrison, G. (2013) The African Presence: Representations of Africa in the construction of Britishness. Manchester: Manchester University Press.

Hopkins, L. and Sriprakash, A. (eds) (2016) The "Poor Child": The cultural politics of education, development and childhood. London: Routledge.

Jefferess, D. (2008) 'Global citizenship and the cultural politics of benevolence'. Critical Literacy: Theories and Practices, 2 (1), 27-36.

Kapoor, I. (2004) 'Hyper-self-reflexive development? Spivak on representing the Third World "Other"', Third World Quarterly, 4 (25), 627-47.

Kleinman, A. and Kleinman, J. (1996) 'The appeal of experience; the dismay of images: Cultural appropriations of suffering in our times'. Daedalus, 125 (1), 1-23.

Krznaric, R. (2008) You Are Therefore I Am: How empathy education can create social change (Oxfam Education and Youth Research Report). Oxford: Oxfam GB.

Landry, D. and MacLean, G. (eds) (1996) The Spivak Reader: Selected works of Gayatri Chakravorty Spivak. New York: Routledge.

Lautze, J. and Giordano, M. (2005) 'Transboundary water law in Africa: Development, nature, and geography'. Natural Resources Journal, 45 (4), 1053-87.

Lewis, M. (2016) A Study of a Focused, Critical Approach to Pupils' Images and Perceptions of Africa (Global Learning Programme Innovation Fund Research Paper 3). London: GLP England.

Leys, C. (1996) The Rise and Fall of Development Theory. Bloomington: Indiana University Press.

Lundy, B.D. (2013) 'Introduction'. In Lundy, B.D. and Negash, S. (eds) Teaching Africa: A guide for the 21st-century classroom. Bloomington: Indiana University Press, 1-18.

Lundy, B.D. and Negash, S. (eds) (2013) Teaching Africa: A quide for the 21st-century classroom. Bloomington: Indiana University Press.

Mahadeo, M. and McKinney, J. (2007) 'Media representations of Africa: Still the same old story?'. Policy and Practice: A Development Education Review, 4, 14-20.

Manzo, K. (2008) 'Imaging humanitarianism: NGO identity and the iconography of childhood'. Antipode, 40 (4), 632-57.

McGough, H. and Hunt, F. (2012) The Global Dimension: A practical handbook for teacher educators. London: Institute of Education.

Merryfield, M.M. and Kasai, M. (2004) 'How are teachers responding to globalization?'. Social Education, 68 (5), 354-9.

Miles, S. (2004) 'Young people in a globalizing world'. In World Youth Report 2003: The global situation of young people. New York: United Nations, 290-309.

Moore-Gilbert, B. (1997) Postcolonial Theory: Contexts, practices, politics. London: Verso. 
Moyo, D. (2009) Dead Aid: Why aid is not working and how there is another way for Africa. London: Allen Lane.

Nothias, T. (2012) 'Definition and scope of Afro-pessimism: Mapping the concept and its usefulness for analysing news media coverage of Africa'. Leeds African Studies Bulletin, 74, 54-62.

Nussbaum, M.C. (2013) Political Emotions: Why love matters for justice. Cambridge, MA: Belknap Press.

Obama, B. (2006) The Audacity of Hope: Thoughts on reclaiming the American dream. New York: Crown.

Pedwell, C. (2012) 'Affective (self-) transformations: Empathy, neoliberalism and international development'. Feminist Theory, 13 (2), 163-79.

Pedwell, C. (2014) Affective Relations: The transnational politics of empathy. New York: Palgrave Macmillan.

Perugini, N. and Zucconi, F. (2017) 'Enjoy Poverty: Humanitarianism and the testimonial function of images'. Visual Studies, 32 (1), 24-32.

Pieterse, J.N. (1991) 'Dilemmas of development discourse: The crisis of developmentalism and the comparative method'. Development and Change, 22 (1), 5-29.

QCA (Qualifications and Curriculum Authority) (2007) The Global Dimension in Action: A curriculum planning guide for schools. London: Qualifications and Curriculum Authority.

Recuber, T. (2015) 'Occupy empathy? Online politics and micro-narratives of suffering'. New Media and Society, 17 (1), 62-77.

Rifkin, J. (c2009) The Empathic Civilization: The race to global consciousness in a world in crisis. New York: Jeremy P. Tarcher.

Rodney, W. (1972) How Europe Underdeveloped Africa. London: Bogle-L'Ouverture Publications.

Ronnenberg, R. (2013) 'Treating the exotic and the familiar in the African history classroom'. In Lundy, B.D. and Negash, S. (eds) Teaching Africa: A guide for the 21st-century classroom. Bloomington: Indiana University Press, 70-5.

Rostow, W.W. (1960) The Stages of Economic Growth: A non-communist manifesto. Cambridge: Cambridge University Press.

Routley, L. (2016) 'Teaching Africa, presenting, representing and the importance of who is in the classroom'. Politics, 36 (4), 482-94.

Said, E.W. (1978) Orientalism. New York: Pantheon Books.

Sarti, A., Schalkers, I. and Dedding, C. (2015) "'I am not poor. Poor children live in Africa": Social identity and children's perspectives on growing up in contexts of poverty and deprivation in the Netherlands'. Children and Society, 29 (6), 535-45.

Scott, M. (2017) 'The myth of representations of Africa: A comprehensive scoping review of the literature'. Journalism Studies, 18 (2), 191-210.

Smith, M.W. (1999) 'Teaching the "Third World": Unsettling discourses of difference in the school curriculum'. Oxford Review of Education, 25 (4), 485-99.

Social Metrics Commission (2018) A New Measure of Poverty for the UK: The final report of the Social Metrics Commission. London: Legatum Institute. Online. https://tinyurl.com/y3ftd63c (accessed 6 March 2019).

Spivak, G. (1988) Can the Subaltern Speak? Basingstoke: Macmillan.

Spivak, G.C. (1990) The Post-Colonial Critic: Interviews, strategies, dialogues. Ed. Harasym, S. New York: Routledge.

Spivak, G.C. (1999) A Critique of Postcolonial Reason: Toward a history of the vanishing present. Cambridge MA: Harvard University Press.

Sutcliffe, B. (2001) 100 Ways of Seeing an Unequal World. London: Zed Books.

Tallon, R. (2012) 'Emotion and agency within NGO development education: What is at work and what is at stake in the classroom?'. International Journal of Development Education and Global Learning, 4 (2), 5-22.

Tallon, R.A.M. (2013) 'What Do Young People Think of Development? An exploration into the meanings young people make from NGO media'. Unpublished PhD thesis, Victoria University of Wellington.

Tikly, L. (2004) 'Education and the new imperialism'. Comparative Education, 40 (2), 173-98.

Todd, S. (2003) Learning from the Other: Levinas, psychoanalysis, and ethical possibilities in education. Albany: State University of New York Press.

Tucker, V. (2001) 'The myth of development: A critique of a Eurocentric discourse'. In Munck, R. and O'Hearn, D. (eds) Critical Development Theory: Contributions to a new paradigm. London: Zed Books, 1-26. 
UNESCO (United Nations Educational, Scientific and Cultural Organization) (1974) 'Recommendation concerning Education for International Understanding, Co-operation and Peace and Education relating to Human Rights and Fundamental Freedoms'. Online. https://tinyurl.com/yxcnto7z (accessed 6 March 2019).

VSO (Voluntary Service Overseas) (2002) The Live Aid Legacy: The developing world through British eyes - A research report. London: Voluntary Service Overseas.

Wiegand, P. (1992) Places in the Primary School: Knowledge and understanding of places at Key Stages 1 and 2. London: Falmer.

World Bank Group (2016) Global Monitoring Report 2015/2016: Development goals in an era of demographic change. Washington, DC: World Bank. 